(117)

\title{
Physico-Chemical and Pathogenic Contamination Status of Groundwater in the Kilinochchi District, Sri Lanka.
}

\author{
Mahagamage M.G.Y.L., Abinaiyan I., Manage P.M.* \\ Center for Water Quality \& Algae Research, Department of Zoology, \\ University of Sri Jayewardenepura, Sri Lanka \\ *pathmalal@sjp.ac.lk
}

\begin{abstract}
Groundwater is a rare and significant natural resource in the world. The rural society in the Kilinochchi District area depend mostly on groundwater sources as the area does not get treated water. Majority of the population in the district are farmers. The present study was carried out to determine the ground water quality along with pathogenic contamination status of groundwater in Kilinochchi area. Thirty wells were sampled in April 2017 and water temperatures, Dissolved Oxygen (DO), $\mathrm{pH}$, conductivity, Total Dissolved Solids (TDS), salinity were measured at the site itself using standard meters. $\mathrm{N}-\mathrm{NO}_{3}{ }^{-}, \mathrm{N}^{-\mathrm{NO}_{2}}{ }^{-}, \mathrm{N}_{-} \mathrm{NH}_{3}$, Total Phosphate (TP), Chemical Oxygen Demand (COD) and total hardness were measured by the following standard spectrophotometric and titrimetric methods. Total coliform and fecal coliform count were obtained from membrane filtration methods. Salmonalla sp. and Shigella sp. were identified using WHO standard methods. The ground water $\mathrm{pH}$ varied between 4.30 to 8.40 whereas DO was between $1.13 \mathrm{mg} / \mathrm{l}$ to $9.18 \mathrm{mg} / \mathrm{l}$. Water TDS, salinity and conductivity ranged between 38 to $5569 \mathrm{mg} / \mathrm{l}, 27$ to $3978 \mathrm{mg} / \mathrm{l}, 60$ to $8840 \mu \mathrm{s} / \mathrm{cm}$ respectively. It was found that most of the wells exceeded the values given by Sri Lankan Standard Institution (SLSI) for drinking water standard. $\mathrm{N}_{-} \mathrm{NO}_{3}{ }^{-}, \mathrm{N}^{-} \mathrm{NO}_{2}^{-}, \mathrm{N}-\mathrm{NH}_{3}$ concentration ranged between $<1.00$ to $17.56 \mathrm{mg} / \mathrm{l},<1.00$ to $2.50 \mu \mathrm{g} / 1$ and $<1.00$ to $21.51 \mu \mathrm{g} / 1$ respectively.TP, COD and total hardness ranged between 47.67 to $191.42 \mu \mathrm{g} / 1,12.81$ to $420.90 \mathrm{mg} / \mathrm{l}$ and 62.0 to 796 $\mathrm{mg} / \mathrm{l}$. Almost all ground water samples exceeded SLSI drinking water standard for COD (10 $\mathrm{mg} / \mathrm{L})$. Thirty seven percent of samples exceeded SLSI drinking water standard for total hardness $(250 \mathrm{mg} / \mathrm{l})$ as well. Sixty percent of samples were contaminated with total coliform whereas $47 \%$ of samples were contaminated with fecal coliform bacteria. Interestingly $37 \%$ of samples were positive for Salmonalla sp. and one groundwater source was contaminated with Shigella sp. The result of the present study revealed that $50 \%$ of ground water sources were not within the SLSI drinking water quality standards. Microbial contamination with Salmonalla sp. shows that continuous monitoring is essential to safeguard ground water consumers and take action accordingly. Therefore, prior treatment is a must before consumption of groundwater for drinking is recommended.
\end{abstract}

Keywords: Groundwater, Kilinochchi District, Water quality, Salmonalla sp, Shigella sp.

Proceedings of the $22^{\text {nd }}$ International Forestry and Environment Symposium 2017 of the Department of Forestry and Environmental Science, University of Sri Jayewardenepura, Sri Lanka 